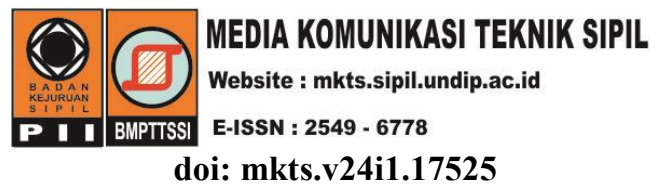

\title{
Sifat Mekanis Beton Normal dengan Campuran Tepung Marmer
}

\author{
"Widodo Kushartomo, Dewi Permata Sari \\ Jurusan Teknik Sipil Fakultas Teknik, Universitas Tarumanagara, Jakarta \\ ${ }^{*}$ widodo@untar.ac.id
}

Received: 5 Februari 2018 Revised: 16 Juli 2018 Accepted: 20 Juli 2018

\begin{abstract}
This study is describe about the mechanical properties of normal concrete by adding of marble flour based on the mixed plan made. The compressive strength of the planned test object $f c$ '20.0 and fc' $30.0 \mathrm{MPa}$ was prepared by using the ACI method. The addition of marble flour in a concrete mixture varies from 0\%, 5\%, $10 \%, 15 \%, 20 \%$ and $25 \%$ to the weight of the cement used. Concrete test specimens were made in the form of cylinders $15.0 \mathrm{~cm}$ in diameter, $30.0 \mathrm{~cm}$ in height and made in the form of concrete beams measuring 15.0 $\mathrm{cm} \times 15.0 \mathrm{~cm} \times 75.0 \mathrm{~cm}$, the type of mechanical testing performed in the form of compressive strength tests on cylindrical specimen, split tensile strength test on cylindrical specimen and flexure test on beam specimen. Curing is done by immersion technique at $25^{\circ} \mathrm{C}$ and the test is done when the concrete is 28 days old. The test results show that the addition of marble flour to the normal concrete mixture can increase its mechanical properties by $26 \%$ for compressive strength, $24 \%$ for split tensile strength, and $17 \%$ for flexural strength.
\end{abstract}

Keywords: Concrete, marble, compressive strength, split tensile strength, flexural strength

\begin{abstract}
Abstrak
Penelitian ini menjelaskan sifat mekanik beton normal dengan penambahan tepung marmer berdasarkan rencana campuran yang dibuat. Kuat tekan benda uji yang direncanakan $f c^{\prime}$ 20,0dan $f c^{\prime}$ 30,0 MPa dibuat menggunakan metode ACI. Penambahan tepung marmer dalam campuran beton bervariasi dari 0\%, 5\%, $10 \%, 15 \%, 20 \%$ dan 25\% terhadap berat semen yang digunakan. Benda uji beton dibuat dalam bentuk silinder berdiameter 15,0 cm, tinggi 30,0 cm dan dibuat dalam bentuk balok beton berukuran 15,0 cm x 15,0 $\mathrm{cm} \times$ 75,0 cm, jenis pengujian mekanik yang dilakukan berupa tes tekan pada benda uji silinder, tes kuat tarik belah pada benda uji silinder dan tes lentur pada benda uji balok. Pemeliharaan dilakukan dengan teknik perendaman pada temperatur $25^{\circ} \mathrm{C}$ dan pengujian dilakukan ketika beton berumur 28 hari. Hasil pengujian memperlihatkan, penambahan tepung marmer ke dalam campuran beton normal dapat meningkatkan sifat mekaniknya sebesar 26\% untuk kuat tekan, 24\% untuk kuat tarik belah, dan 17\% untuk kuat lentur.
\end{abstract}

Kata kunci: Beton, marmer, kuat tekan, kuat tarik belah, kuat lentur

\section{Pendahuluan}

Marmer merupakan salah satu material penting yang digunakan dalam bangunan khususnya sebagai elemen dekoratif. Dalam industri batu ornamen, batuan jenis ini mempunyai nilai ekonomis yang sangat baik. Namun dalam proses pembuatannya untuk menjadi elemen dekoratif, 20-30\% dari produk akhir hasil pengolahan dihasilkan limbah berupa pecahan batu marmer dan tepung marmer (Aliabdo et al., 2014). Jika tidak dilakukan penanganan yang tepat, limbah ini dapat menyebabkan dampak serius pada lingkungan, air tanah dan kesehatan. Jika air limbah yang tercampur dengan tepung marmer dibuang ke lingkungan tanpa diolah terlebih dahulu dapat mempengaruhi morfologi, hidrologi dan kesuburan tanah di daerah sekitar pembuangan limbah dengan mengurangi porositas dan permeabilitasnya. Sedangkan partikel udara halus dari pengolahan limbah ini bahkan bisa menimbulkan efek visual, gangguan pernafasan 
dan kulit (Rana et al., 2015). Penelitian penggunaan material dengan ukuran partikel sangat halus sebagai bahan penyusun beton seperti abu terbang, silica fume, dan tepung marmer terbukti berhasil dalam meningkatkan sifat mekanik beton normal, beton mutu tinggi dan reactive powder concrete (Kushartomo et al., 2013).

Penelitian beton menggunakan limbah marmer sebagai pengganti pasir dilakukan oleh Kalchuri \& Chandak (2015), jumlah tepung marmer yang digunakan sebagai pengganti pasir dipersiapkan dalam berbagai jumlah $(5 \%, 10 \%, 20 \%, 30 \%$ dan $40 \%)$. Penelitian yang dilakukan menghasilkan terjadi peningkatan kuat tekan beton bila pasir diganti mencapai $20 \%$, dan apabila jumlah pasir yang diganti melebihi 20\% maka akan terjadi penurunan kuat tekan.

Susilowati (2011) meneliti pengaruh kandungan tepung marmer sebesar 0\%, 5\%, 10\%, dan $15 \%$ dari berat semen. Penggantian limbah marmer terhadap sejumlah semen pada adukan beton normal dapat meningkatkan kuat tekan beton hanya pada beton marmer kadar 5\%, karena kadar tersebut optimum untuk mengisi rongga/voids, sedangkan pada kadar $10 \%$ dan $15 \%$ terjadi penurunan kuat tekan.

Istiqomah \& Kurnia (2013) meneliti pengaruh kandungan tepung marmer pada beton. Jumlah tepung marmer yang digunakan sebagai campuran pada beton dipersiapkan dalam berbagai jumlah $(0 \%, 5 \%, 10 \%, 20 \%, 30 \%)$. Berdasarkan pengujian kuat tekan pada umur 49 hari memperlihatkan penambahan tepung marmer optimum berada diantara 10 - 20\% dari berat semen. Pada penambahan tepung marmer sebesar $10-20 \%$ dapat menaikkan kuat tekannya sebesar $10 \%$ dari kuat tekan beton normal.

Beberapa tahun belakang ini banyak penelitian yang membuktikan penggunaan bahan tambahan berupa mineral pada beton berhasil dalam meningkatkan sifat-sifat beton baik pada beton segar maupun beton keras (Galinska \& Czarnecki, 2017 dan King et al., 2012). Penggunaan tepung marmer sebagai mineral bahan tambahan dalam beton belum banyak mendapat perhatian dari para peneliti. Data-data teknis yang berkaitan dengan tepung marmer dalam campuran beton masih jauh dari sempurna dan banyak parameter yang perlu dipelajari dengan lebih mendalam.

Keterbatasan data teknis penggunaan tepung marmer dalam beton berdampak pada belum adanya kesimpulan yang baik terhadap jumlah optimum tepung marmer harus digunakan untuk menghasilkan sifat mekanik yang maksimum sebagai bahan campuran mineral dalam beton. Persentase jumlah optimum tepung marmer diperkirakan tergantung pada kadar semen, tingkat kehalusan dan metode pemeliharaan. Pemeriksaan komposisi kimia yang dilakukan terhadap tepung marmer didominasi oleh $(\mathrm{CaO})$ dan juga beberapa bahan lain diantaranya $\left(\mathrm{SiO}_{2}\right),\left(\mathrm{Al}_{2} \mathrm{O}_{3}\right)$ dan $\left(\mathrm{Fe}_{2} \mathrm{O}_{3}\right)$. Unsur-unsur tersebut merupakan bahan baku utama dalam pembuatan semen, sehingga tepung marmer mampu bekerja sebagai bahan pengikat pada beton bila terjadi reaksi pozzolanik. Demikian juga dengan ukuran butiran yang sangat halus, penambahan tepung marmer pada beton dapat berfungsi sebagai bahan pengisi pori-pori beton.

Pada umumnya limbah tepung marmer merupakan material yang tidak diinginkan, terlebih jika jumlah limbah yang dihasilkan sangat melimpah maka limbah tersebut akan berdampak negatif pada lingkungan. Pada penelitian ini akan dilakukan rangkaian pengujian dan analisis terkait komposisi kimia dan sifat mekanis beton campuran tepung marmer berupa kuat tekan, kuat tarik belah, dan kuat lentur. Diharapkan penelitian ini dapat menjadi rujukan untuk membantu mengurangi pencemaran lingkungan.

\section{Metode}

Pengujian sifat mekanis beton campuran tepung marmer berupa kuat tekan, kuat tarik belah, dan kuat lentur dilaksanakan di Laboratorium Konstruksi dan Teknologi Beton Jurusan Teknik Sipil Universitas Tarumanagara. Sejumlah benda uji disiapkan berupa silinder dengan ukuran diameter $15,0 \mathrm{~cm}$ dan tinggi $30,0 \mathrm{~cm}$ dan balok berukuran $15,0 \mathrm{~cm}$ x 15,0 cm x 75,0 cm. Rencana campuran menggunakan metode ACI 211 dengan mutu beton direncanakan $f_{c}^{\prime} 20,0 \mathrm{MPa}$ dan $f_{c}^{\prime} 30$ MPa. Tepung marmer yang ditambahkan pada setiap mutu dalam campuran beton divariasikan dari $0 \%$ yang digunakan sebagai kontrol, kemudian $5 \%, 10 \%, 15 \% 20 \%$ dan $25 \%$.

Seluruh benda uji dipelihara dengan teknik perendaman pada temperatur $25^{\circ} \mathrm{C}$ selama 26 hari dan diuji ketika umurnya telah mencapai 28 hari. Selain pengujian mekanik juga dilakukan pengujian properties agregat, pengujian komposisi kimia dan pengujian ukuran butiran tepung marmer serta pemeriksaan mikroskopis menggunakan scaning electron microscopy (SEM). Seluruh agregat yang digunakan diperoleh dari daerah sekitar kampus Universitas Tarumanagara dan tepung marmer diambil dari pabrik produsen batu marmer di daerah Cikarang, Jawa Barat. 
Tabel 1. Sifat fisika dan kimia semen PCC (Indrawati, 2007)

\begin{tabular}{|c|c|c|c|c|}
\hline \multirow{2}{*}{ Item } & \multirow{2}{*}{ Satuan } & \multirow{2}{*}{$\begin{array}{c}\text { Standar } \\
\text { SNI }\end{array}$} & \multicolumn{2}{|c|}{ PCC } \\
\hline & & & Range & Tipikal \\
\hline Volume kadar udara dalam mortar & $\%$ & $\leq 12,0$ & $3,0-11,0$ & 7,000 \\
\hline Kehalusan & $\mathrm{m}^{2} / \mathrm{kg}$ & $\geq 280$ & $350-420$ & 385,000 \\
\hline \multicolumn{5}{|l|}{ Ekspansi dengan: } \\
\hline Autoclave & $\%$ & $\leq 0,08$ & $0,03-0,20$ & 0,115 \\
\hline Shrinkage & $\%$ & $\leq 0,20$ & $0,10-0,20$ & 0,150 \\
\hline \multicolumn{5}{|l|}{ Waktu pengikatan } \\
\hline Awal & menit & $\geq 45$ & $110-150$ & 130,000 \\
\hline Akhir & menit & $\geq 375$ & $260-350$ & 305,000 \\
\hline \multicolumn{5}{|l|}{ Kuat tekan } \\
\hline 3 hari & $\mathrm{kg} / \mathrm{cm}^{2}$ & $\geq 125$ & $210-250$ & 230,000 \\
\hline 7 hari & $\mathrm{kg} / \mathrm{cm}^{2}$ & $\geq 200$ & $280-320$ & 300,000 \\
\hline 28 hari & $\mathrm{kg} / \mathrm{cm}^{2}$ & $\geq 250$ & $390-430$ & 410,000 \\
\hline \multicolumn{5}{|l|}{ Pengikatan semu } \\
\hline Penetrasi akhir & $\%$ & $\geq 50$ & $110-150$ & 130,000 \\
\hline Specific grafity & $\mathrm{g} / \mathrm{cm}^{3}$ & - & $3,00-3,10$ & 3,050 \\
\hline Panas hidrasi, 7 hari & $\mathrm{kal} / \mathrm{g}$ & - & $60,0-70,0$ & 65,000 \\
\hline Panas hidrasi, 28 hari & $\mathrm{kal} / \mathrm{g}$ & - & $70,0-85,0$ & 77,500 \\
\hline $\mathrm{SiO}_{2}$ & $\%$ & & $20,0-25,0$ & 22,500 \\
\hline $\mathrm{Al}_{2} \mathrm{O}_{3}$ & $\%$ & & $5,0-7,0$ & 6,000 \\
\hline $\mathrm{Fe}_{2} \mathrm{O}_{3}$ & $\%$ & & $3,0-4,0$ & 3,500 \\
\hline $\mathrm{CaO}$ & $\%$ & & $55,0-65,0$ & 60,000 \\
\hline $\mathrm{MgO}$ & $\%$ & & $1,5-3,0$ & 2,250 \\
\hline $\mathrm{SO}_{3}$ & $\%$ & $\leq 4,0$ & $2,0-2,5$ & 2,250 \\
\hline Free lime & $\%$ & & $0,5-1,5$ & 1,000 \\
\hline Total alkali & $\%$ & & $0,3-0,6$ & 0,450 \\
\hline Chloride & $\%$ & & $0,01-0,02$ & 0,015 \\
\hline
\end{tabular}

\section{Deskripsi material}

Dalam penelitian ini semen yang digunakan berupa portland composite cement (PCC) dan telah memenuhi standar SNI 15-7064-2004. Sifat fisika dan kimia semen PCC yang digunakan ditunjukkan pada Tabel 1. Jenis semen PCC dipilih berdasarkan tingkat kemudahan dalam perolehannya dan juga produksi semen PCC lebih ramah terhadap penggunaan bahan baku alam. Agregat halus yang digunakan berasal dari daerah Rangkas sedangkan agregat kasar berasal dari daerah Sudamanik dengan properties seperti ditunjukkan pada Tabel 2.

Tabel 2. Properties agregat halus dan kasar

\begin{tabular}{lccc}
\hline \multirow{2}{*}{\multicolumn{1}{c}{ Properties }} & \multirow{2}{*}{ Satuan } & \multicolumn{2}{c}{ Hasil pengujian } \\
\cline { 2 - 4 } & & Halus & Kasar \\
\hline Kadar lumpur & $\%$ & 12,167 & 1,583 \\
Kadar organis & - & minimum & minimum \\
Kadar air & $\%$ & 4,750 & 1,500 \\
Berat jenis & $\mathrm{g} / \mathrm{m}^{3}$ & 2,070 & 2,235 \\
Penyerapan & $\%$ & 20,000 & 1,700 \\
Gradasi butiran & - & Zona 2 & $4,8-38$ \\
Modulus kehalusan & - & 2,600 & 7,800 \\
\hline
\end{tabular}

Tepung marmer diambil dari pabrik produsen batu marmer di daerah Cikarang Jawa Barat, merupakan hasil pemotongan dan penghalusan batu marmer. Tepung marmer yang diambil masih tercampur dengan air sehingga perlu dikeringkan terlebih dahulu dengan oven pada temperatur $105 \pm 5^{\circ} \mathrm{C}$ selama 24 jam, kemudian digiling menggunakan mesin los angelos supaya menjadi tepung. Komposisi kimia dan komposisi fisika dapat dilihat pada Tabel 3 dan 4. Ukuran butiran tepung marmer ditunjukkan dalam Gambar 1.

Tabel 3. Komposisi kimia tepung marmer

\begin{tabular}{lrc}
\hline Parameter & Satuan & Hasil \\
\hline $\mathrm{CaO}$ & $\%$ & 45,24 \\
$\mathrm{SiO}_{2}$ & $\%$ & 9,65 \\
$\mathrm{MgCO}_{3}$ & $\%$ & 3,04 \\
$\mathrm{Al}_{2} \mathrm{O}_{3}$ & $\%$ & 2,85 \\
$\mathrm{Fe}_{2} \mathrm{O}_{3}$ & $\%$ & 1,05 \\
\hline
\end{tabular}

Tabel 4. Komposisi fisika tepung marmer

\begin{tabular}{lll}
\hline Properties & Satuan & Hasil \\
\hline Specific gravity & $\mathrm{g} / \mathrm{cm}^{3}$ & 2,760 \\
$\mathrm{D}_{60}$ & $\mathrm{~mm}$ & 0,013 \\
Warna & - & Putih \\
\hline
\end{tabular}




\section{Proporsi campuran}

Sebuah campuran digunakan sebagai pengontrol (Mix-0) dan lima campuran (Mix-5 sampai Mix-25) dengan penambahan tepung marmer, disiapkan untuk pembuatan benda uji dan pengujiannya berupa kuat tekan, kuat tarik belah dan kuat lentur. Setelah penuangan kedalam cetakan, benda uji di jaga selama 24 jam, kemudian dibuka dan direndam dalam air bertemperatur $25^{\circ} \mathrm{C}$ selama 26 hari. Pada umur 27 hari benda uji di keluarkan dari bak perendaman dan dibiarkan kering udara untuk di tes pada umur 28 hari. Tabel 5 dan 6 memperlihatkan proporsi material untuk setiap campuran.

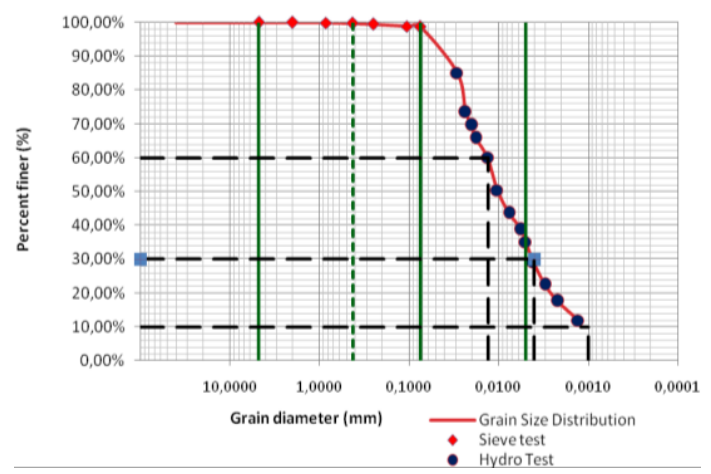

Gambar 1. Distribusi ukuran butiran tepung marmer

\section{Prosedur pengujian}

Setelah pemeliharaan dalam air, seluruh benda uji di tes menggunakan prosedur baku yang berlaku secara internasional.

\section{Pengujian kuat tekan beton}

Pengujian kuat tekan dilakukan mengikuti prosedur baku ASTM C39. Pengujian kuat tekan beton dapat dilihat pada Gambar 2(a). Perhitungan kuat tekan beton dapat dilihat sebagai berikut:

$f_{c}^{\prime}=\frac{P}{A}$

dimana $f_{c}^{\prime}$ adalah kuat tekan silinder (MPa), $P$ adalah beban maksimum $(\mathrm{N})$, dan $A$ adalah luas bidang tekan $\left(\mathrm{mm}^{2}\right)$.

\section{Pengujian kuat tarik belah beton}

Pengujian kuat tarik belah menggunakan prosedur baku ASTM C496.Pengujian kuat tarik belah beton dapat dilihat pada Gambar 2(b). Perhitungan kuat tarik belah dapat dilihat sebagai berikut:

$f_{c t}=\frac{2 P}{\pi l d}$

diamana $f_{c t}$ merupakan kuat tarik belah beton (MPa), $P$ merupakan beban maksimum yang ditunjukkan oleh mesin uji (N), $l$ merupakan panjang spesimen $(\mathrm{mm})$, dan $d$ merupakan diameter spesimen $(\mathrm{mm})$.

\section{Pengujian kuat lentur beton}

Pengujian kuat lentur balok menggunakan prosedur baku ASTM C78, yaitu metode pengujian kuat lentur balok (modulus of rupture) beton dengan beban diterapkan pada dua titik pada sepertiga dari panjang bentang (third point loading).

Tegangan maksimum terjadi pada bagian $1 / 3$ bagian balok. Rekayasa pembebanan dan momen yang terjadi dapat dilihat pada Gambar 3 . Besarnya momen yang dapat mematahkan benda uji adalah momen akibat beban maksimum dari mesin dengan mengabaikan berat sendiri. Pengujian kuat lentur beton dapat dilihat pada Gambar 2(c).

Tabel 5. Proporsi campuran $f_{c}^{\prime} 20,0$ MPa material tiap $\mathrm{m}^{3}$

\begin{tabular}{lcccccr}
\hline \multicolumn{1}{c}{ Material } & Satuan & Mix-0 & Mix-5 & Mix-10 & Mix-15 & Mix-20 \\
\hline Semen & $\mathrm{Kg}$ & 253 & 253 & 253 & 253 & 253,0 \\
Air & $\mathrm{Kg}$ & 175 & 175 & 175 & 175 & 175,0 \\
Pasir & $\mathrm{Kg}$ & 516 & 516 & 516 & 516 & 516,0 \\
Kerikil & $\mathrm{Kg}$ & 1084 & 1084 & 1084 & 1084 & 1084,0 \\
Marmer & $\mathrm{Kg}$ & 0 & 12,6 & 25,3 & 38,0 & 50,7 \\
\hline
\end{tabular}

Tabel 6. Proporsi campuran $f_{c}^{\prime} 30,0$ MPa material tiap $\mathrm{m}^{3}$

\begin{tabular}{lccccccc}
\hline \multicolumn{1}{c}{ Material } & Satuan & Mix-0 & Mix-5 & Mix-10 & Mix-15 & Mix-20 & Mix-25 \\
\hline Semen & $\mathrm{Kg}$ & 324 & 324 & 324 & 324 & 324 & 324,0 \\
Air & $\mathrm{Kg}$ & 175 & 175 & 175 & 175 & 175 & 175,0 \\
Pasir & $\mathrm{Kg}$ & 552 & 552 & 552 & 552 & 552 & 552,0 \\
Kerikil & $\mathrm{Kg}$ & 995 & 995 & 995 & 995 & 995 & 995,0 \\
Marmer & $\mathrm{Kg}$ & 0 & 16,2 & 32,4 & 48,6 & 64,8 & 81,0 \\
\hline
\end{tabular}




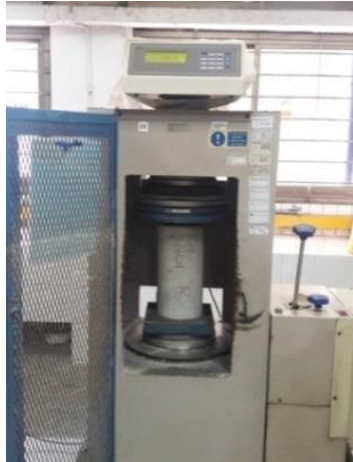

(a)

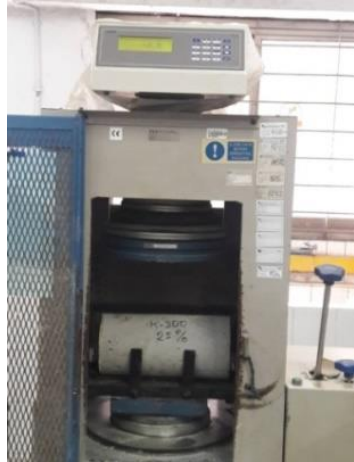

(b)

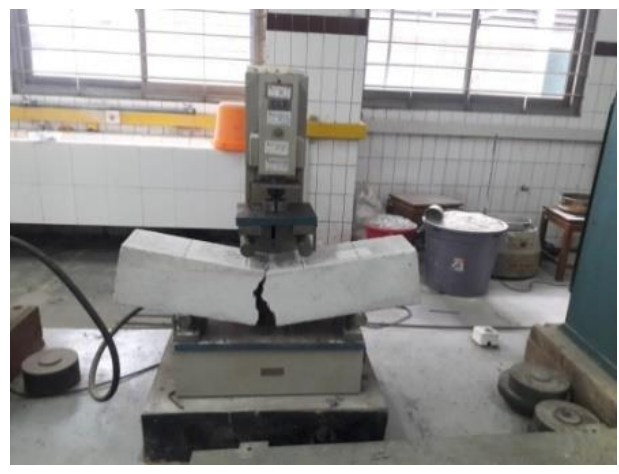

(c)

Gambar 2. Pengujian mekanik beton: (a) kuat tekan (b) kuat tarik belah (c) kuat lentur

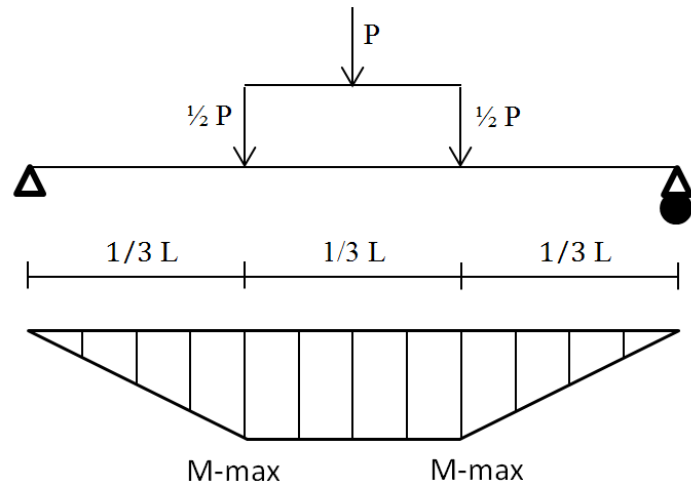

Gambar 3. Momen akibat beban P

Besarnya momen maksimum dapat dilihat sebagai berikut:

$M=\frac{1}{2} P \frac{1}{3} L=\frac{1}{6} P L$

dimana $P$ merupakan beban maksimum $(\mathrm{N}), L$ merupakan panjang bentang $(\mathrm{mm})$.

Secara umum persamaan kuat lentur balok dapat ditulis :

$f_{r}=\frac{M}{S}=\frac{\frac{1}{6} P L}{\frac{1}{6} b h^{2}}=\frac{P L}{b h^{2}}$

Dalam menghitung kuat lentur dibagi dalam 3 kategori sesuai dengan letak bidang patahannya. Benda uji yang digunakan berupa balok dengan ukuran $15,0 \mathrm{~cm} \times 15,0 \mathrm{~cm} \times 75,0 \mathrm{~cm}$. Rumusrumus perhitungan yang digunakan adalah:

Perhitungan kuat lentur dapat dilihat sebagai berikut:

1. Bidang patah terletak di daerah pusat (daerah $1 / 3$ jarak titik perletakan bagian tengah). Daerah patahan dan pembebanannya dapat dilihat pada Gambar 4 dan 5.

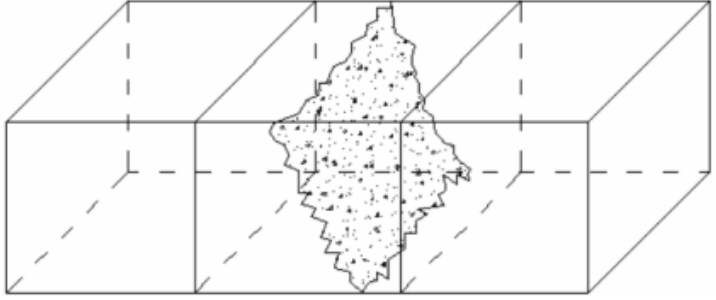

Gambar 4. Patah pada $1 / 3$ bentang tengah (SNI 03-4431-2011)

Sesuai dengan kondisi di atas maka nilai kuat lentur balok dapat dihitung sebagai berikut:

$$
f_{r}=\frac{P L}{b h^{2}}
$$

dimana $f_{r}$ merupakan kuat lentur beton (MPa), $P$ merupakan beban maksimum yang ditunjukkan oleh mesin uji (N), L merupakan panjang bentang antar perletakan $(\mathrm{mm}), \mathrm{b}$ merupakan lebar benda uji (mm), h merupakan tinggi benda uji (mm).

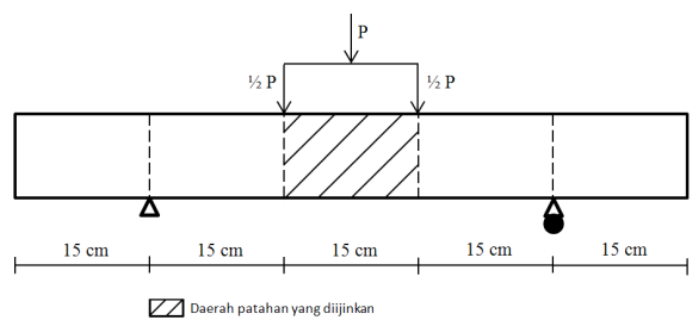

\section{Gambar 5. Daerah patahan tipe satu pada} benda uji

2. Untuk pengujian dimana patahnya benda uji ada diluar pusat (daerah $1 / 3$ jarak titik perletakan bagian tengah), dan jarak antara titik pusat dan titik patah kurang dari 5\% dari jarak antara titik perletakan maka kuat lentur beton dihitung menurut persamaan sebagai berikut. Daerah patahan dan pembebanannya dapat dilihat pada Gambar 6 dan 7. 


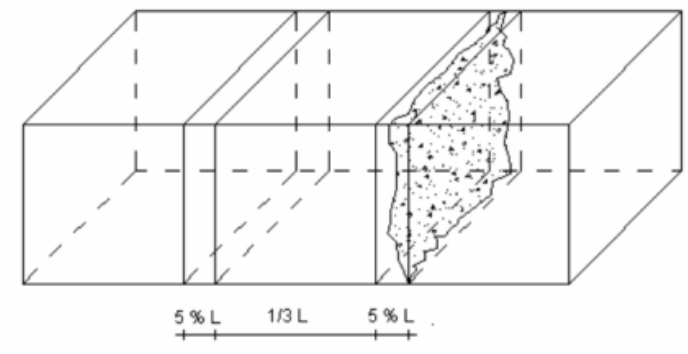

Gambar 6. Patah di luar $1 / 3$ bentang tengah dan garis patah pada $<5 \%$ dari bentang

(SNI 03-4431-2011)

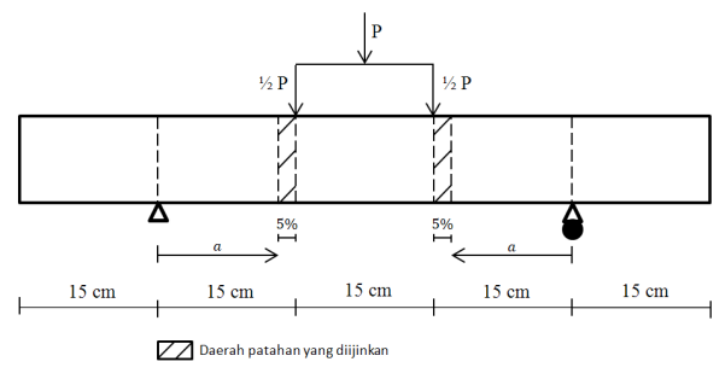

Gambar 7. Daerah patahan tipe dua pada benda uji

Sesuai dengan kondisi di atas maka nilai kuat lentur balok dapat dihitung sebagai berikut:

$$
f_{r}=\frac{3 P a}{b h^{2}}
$$

dimana $f_{r}$ merupakan kuat lentur beton (MPa), $\mathrm{P}$ merupakan beban maksimum yang ditunjukkan oleh mesin uji $(\mathrm{N}), \mathrm{L}$ jarak antara titik retak ke perletakan (mm), b merupakan lebar benda uji (mm), h merupakan tinggi benda uji (mm).

3. Untuk benda uji yang patahnya di luar pusat (daerah $1 / 3$ jarak titik perletakan bagian tengah) dan jarak antara titik pembebanan dan titik patah lebih dari $5 \%$ bentang, hasil pengujian tidak digunakan. Daerah patahan dan pembebanannya dapat dilihat pada Gambar 8 .

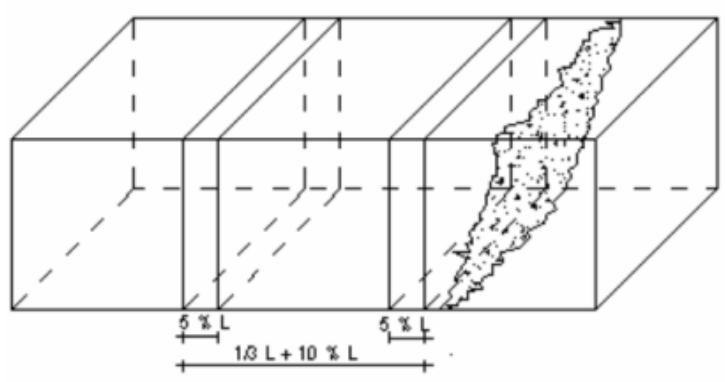

Gambar 8. Patah di luar $1 / 3$ bentang tengah dan garis patah pada $>5 \%$ dari bentang

(SNI 03-4431-2011)

\section{Hasil dan Pembahasan}

Pengujian kuat tekan yang dilakukan terhadap seluruh benda uji, memiliki nilai rata-rata seperti yang ditunjukkan pada Tabel 7, 8 dan 9 .

Tabel 7. Nilai rata-rata kuat tekan benda uji

\begin{tabular}{lccc}
\hline \multirow{2}{*}{ Kode } & \multirow{2}{*}{ Satuan } & \multicolumn{2}{c}{ Kuat tekan $(\mathbf{M P a})$} \\
\cline { 3 - 4 } & & $f_{c}{ }^{\prime} \mathbf{2 0 , 0}$ & $f_{c}{ }^{\prime} \mathbf{3 0 , 0}$ \\
\hline Mix-0 & MPa & 11,94 & 22,39 \\
Mix-5 & MPa & 12,59 & 26,51 \\
Mix-10 & MPa & 14,29 & 27,23 \\
Mix-15 & MPa & 16,83 & 29,28 \\
Mix-20 & MPa & 12,30 & 23,96 \\
Mix-25 & MPa & - & 23,33 \\
\hline
\end{tabular}

Tabel 8. Nilai rata-rata kuat tarik belah benda uji

\begin{tabular}{lccc}
\hline \multirow{2}{*}{ Kode } & \multirow{2}{*}{ Satuan } & \multicolumn{2}{c}{ Kuat tarik belah (MPa) } \\
\cline { 3 - 4 } & & $\boldsymbol{f}_{\boldsymbol{c}}{ }^{\mathbf{2 0 , 0}}$ & $\boldsymbol{f}_{\boldsymbol{c}}{ }^{\mathbf{3 0 , 0}}$ \\
\hline Mix-0 & $\mathrm{MPa}$ & 1,66 & 22,39 \\
Mix-5 & $\mathrm{MPa}$ & 1,77 & 26,51 \\
Mix-10 & $\mathrm{MPa}$ & 1,98 & 27,23 \\
Mix-15 & $\mathrm{MPa}$ & 2,20 & 29,28 \\
Mix-20 & $\mathrm{MPa}$ & 1,69 & 23,96 \\
Mix-25 & $\mathrm{MPa}$ & - & 23,33 \\
\hline
\end{tabular}

Tabel 9. Nilai rata-rata kuat lentur benda uji

\begin{tabular}{lccc}
\hline \multirow{2}{*}{ Kode } & \multirow{2}{*}{ Satuan } & \multicolumn{2}{c}{ Kuat lentur (MPa) } \\
\cline { 3 - 4 } & & $f_{c}^{\prime} \mathbf{2 0 , 0}$ & $f_{c}^{\prime} \mathbf{3 0 , 0}$ \\
\hline Mix-0 & MPa & 4,00 & 22,39 \\
Mix-5 & MPa & 4,17 & 26,51 \\
Mix-10 & MPa & 4,27 & 27,23 \\
Mix-15 & MPa & 4,50 & 29,28 \\
Mix-20 & MPa & 3,94 & 23,96 \\
Mix-25 & MPa & 3,80 & 23,33 \\
\hline
\end{tabular}

Berdasarkan pengujian yang dilakukan peningkatan kuat tekan terjadi ketika campuran beton menggunakan tepung marmer, peningkatan terjadi terus sampai penambahan tepung marmer sebanyak $15 \%$, setelah itu baru terjadi penurunan kuat tekan ketika jumlah tepung marmer yang ditambahkan sebanyak $20 \%$ dan $25 \%$. Namun demikian nilai kuat tekan beton yang menggunakan tepung marmer 20\% dan 25\% masih lebih tinggi dibandingkan dengan beton yang tidak menggunakan campuran tepung marmer,demikian juga berlaku untuk pengujian lain yaitu tes belah dan tes lentur (Gambar 9 dan 10).

Berdasarkan nilai rata-rata terhadap keseluruhan hasil pengujian, penggunaan tepung marmer dapat meningkatkan sifat mekanik beton sebesar $26 \%$ untuk kuat tekan, 24\% untuk kuat tarik belah, dan $17 \%$ untuk kuat lentur. Peningkatan kekuatan mekanik beton ini dapat dijelaskan sebagai berikut, tingkat kehalusan butiran semen yang disajikan dalam Tabel 1 yaitu sebesar $385 \mathrm{~m}^{2} / \mathrm{kg}$ artinya setara dengan ukuran saringan 200 mesh atau ratarata ukuran besar butir sebesar $0,074 \mathrm{~mm}$, 
sedangkan ukuran butiran tepung marmer yang terukur berdasarkan Tabel 4 rata-rata sebesar $0,013 \mathrm{~mm}$.

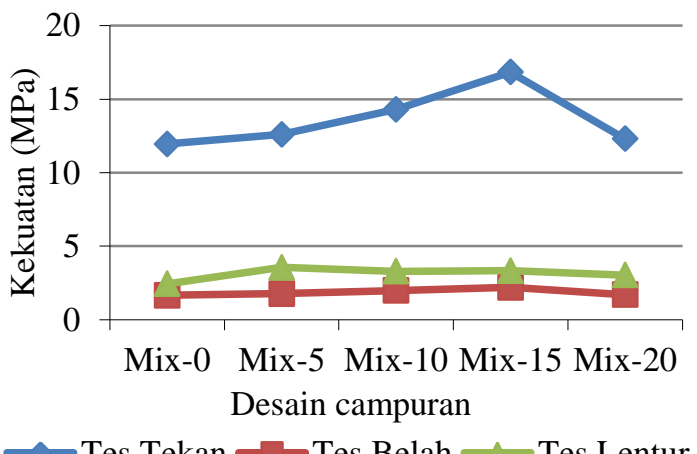

\section{Gambar 9. Nilai rata-rata pengujian benda uji} $f_{c}{ }^{\prime} 20,0 \mathrm{MPa}$

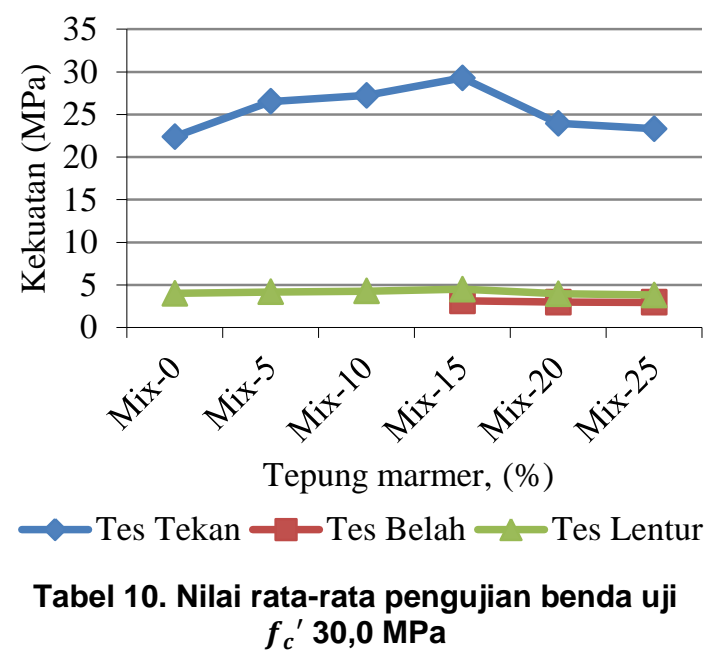

Berdasarkan data tersebut maka ukuran butiran tepung marmer jauh lebih kecil bila dibandingkan dengan ukuran butiran semen, ini berarti tepung marmer akan mengisi void yang terbentuk didalam beton seperti ditunjukkan pada Gambar 11, sehingga beton menjadi semakin kompak dan berdampak pada peningkatan sifat mekanisnya.

Kekuatan mekanis tertinggi dicapai ketika jumlah tepung marmer yang dimasukkan sebesar $15 \%$, ini menunjukkan sebagian besar void telah terisi oleh butiran tepung marmer, sedangkan bila jumlah tepung marmer yang ditambahkan lebih dari $15 \%$ menyebabkan terjadi penurunan nilai kekuatan mekanis. Penurunan ini diakibatkan karena jumlah tepung marmer yang berlebihan, kelebihan tepung marmer tersebut justru bertindak sebagai pengotor dalam campuran dan menghalangi pengikatan yang terjadi antara pasta semen dengan agregat.

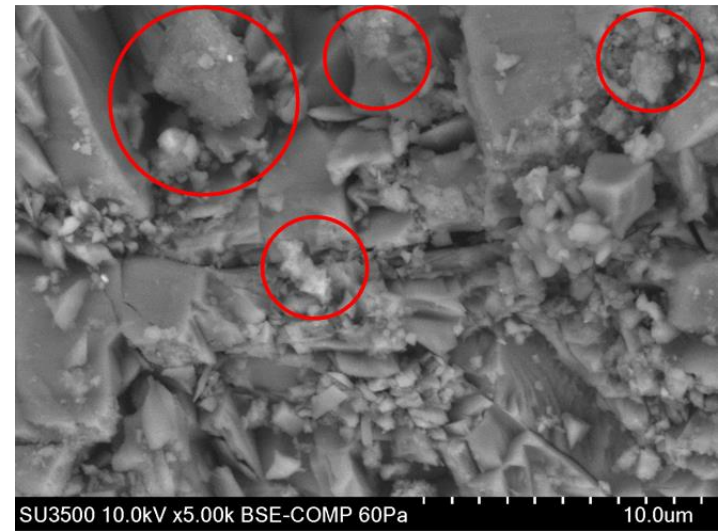

Tabel 11. Butiran tepung marmer dalam void beton

Komposisi kimia tepung marmer yang menyerupai komposisi kimia semen, dalam penelitian ini belum menunjukkan peranan dalam peningkatan kekuatan mekanik. Peningkatan kekuatan beton ditinjau dari komposisi kimia dapat terjadi apabila komposisi kimia pada tepung marmer bertemu dengan material yang mengandung silika aktif seperti pozzolanik material yaitu silica fume, abu terbang atau abu vulkanik. Pozzolanik material memicu terjadinya reaksi pozzolanik antara produk hidrasi semen dengan silika aktif, reaksi tersebut menghasilkan material pengikat baru dalam beton yang disebut dengan tobermorite sehingga beton menjadi bertambah kuat (Kushartomo et al., 2013).

Dalam penelitian ini tidak digunakan material pozzolanik dalam rencana campuran beton, sehingga tidak terjadi reaksi pozzolanik. Berdasar keterangan tersebut, komposisi kimia tepung marmer tidak berkontribusi terhadap peningkatan kekuatan beton. Analisa ini dikuatkan pula dengan tidak ditemukannya gambar tobermorite pada struktur mikro beton seperti disajikan pada Gambar 11.

\section{Kesimpulan}

Berdasar hasil pengujian dan analisa yang telah dilakukan maka dapat disimpulan bahwa Penambahan tepung marmer ke dalam campuran beton normal dapat meningkatkan kekuatan mekanisnya sebesar 26\% untuk kuat tekan, $24 \%$ untuk kuat tarik belah, dan $17 \%$ untuk kuat lentur. Peningkatan kekuatan mekanis beton normal terjadi akibat tepung marmer mengisi void yang terdapat dalam beton sehingga beton menjadi semakin padat dan kompak. Ukuran butiran tepung marmer yang jauh lebih kecil dari pada ukuran butiran semen, memudahkan tepung marmer mengisi setiap void yang terbentuk didalam beton. 
Penambahan tepung marmer sebesar $15 \%$ terhadap berat semen pada campuran beton normal, menyebabkan peningkatan kekuatan mekanik beton secara maksimal. Komposisi kimia tepung marmer tidak berkontribusi pada peningkatan kekuatan mekanik beton, komposisi kimia tepung marmer akan berkontribusi pada peningkatan kekuatan beton bila menyebabkan terjadinya reaksi pozzolanik. Penggunaan tepung marmer sebagai bahan campuran beton, membatu mengurangi pencemaran lingkungan yang dihasilkan oleh limbah industri pengolahan batu marmer.

\section{Saran}

Berdasarkan penelitian yang sudah dilakukan, penulis ingin memberikan beberapa saran yaitu Perlu dilakukan pengujian sifat mekanis yang lain seperti modulus elastisitas dan sebagainya. Perlu dilakukan percobaan untuk campuran mutu beton yang lain.

\section{Daftar Pustaka}

ACI Commitee 211. (1991). Standard Practice for Selecting Proportions for Normal, Heavy Weight and Mass Concerete. American Concrete Institute.

Aliabdo, A. A., Elmoaty, A. E. M. A., \& Auda, E. M. (2014). Re-use of waste marble dust in the production of cement and concrete. Construction and Building Materials, 50, 28-41.

ASTM Internasional. (2002). Standar Test Method for Compressive Strength of Cylindrical Concrete Speciments, Section 4, Vol. 04.02, ASTM C39.

ASTM Internasional. (2002). Standar Test Method for Flexural Strength of Concrete, Section 4, Vol. 04.02, ASTM C78.

ASTM Internasional. (2002). Standar Test Method for Splitting Tensile Strength of Cylindrical Concrete Speciments, Section 4, Vol. 04.02, ASTM C496.

Badan Standarisasi Nasional. (2011). SNI 034431-2011 Cara Uji Kuat Lentur Beton Normal dengan Dua Titik Pembebanan. Bandung: Badan Standarisasi Nasional.

Galińska, A., \& Czarnecki, S. (2017, October). The Effect of Mineral Powders Derived From Industrial Wastes on Selected Mechanical Properties of Concrete. In IOP Conference Series: Materials Science and Engineering, 245(3), p. 032039). IOP Publishing.

Indrawati, V. (2007). Konsep, Bahan Aditif Mineral, Karakteristik dan Pengendalian Kualitas PCC Tiga Roda. Seminar Nasional Rekayasa Material dan Konstruksi Beton.

Istiqomah \& Kurnia, S. (2013, Oktober). Pengaruh Tepung Marmer sebagai Bahan Pengisi pada Beton. Konferensi Nasional Teknik Sipil 7 (KoNtekS7), Universitas Sebelas Maret, Surakarta.

King, D., Fict, H., Dip, M., \& Chartered, M. C. I. M. (2012, August). The Effect of Silica Fume on The Properties of Concrete as Defined in Concrete Society Report 74, Cementitious Materials. In 37th Conference on Our World in Concrete and Structures, Singapura .

Kalchuri, B. S., \& Chandak, R. (2015). Study on concrete using marble powder waste as partial replacement of sand. International Journal of Engineering Research and Applications, 5(4), 87-89.

Kushartomo, W., Makarim, C. A., Supartono, F. X., \& Sumawiganda, S. (2013). Pengaruh penambahan quartz powder pada reactive powder concrete terhadap terbentuknya kalsium-silikathidrat. Journal of Civil Engineering, 20(3), 187-194.

Rana, A., Kalla, P., \& Csetenyi, L. J. (2015). Sustainable use of marble slurry in concrete. Journal of Cleaner Production, 94, 304-311.

Susilowati. (2011). Pemanfaatan serbuk marmer sebagai bahan alternatif pengganti semen pada campuran beton normal, Jurnal Arsitektur Universitas Bandar Lampung, 1(2), 16-24. 